Journal of Social Sciences 6 (3): 443-446, 2010

ISSN 1549-3652

(C) 2010 Science Publications

\title{
Indigenous Students and the Learning of English
}

\author{
${ }^{1}$ Shahrier Pawanchik, ${ }^{2}$ Anton Abdulbasah Kamil and ${ }^{3}$ Fatan Hamamah Yahaya \\ ${ }^{1}$ Department of English, \\ ${ }^{2}$ Department of Mathematics, \\ ${ }^{3}$ Department of Sociology and Anthropology, \\ School of Distance Education, University Sains Malaysia, \\ 11800 USM, Penang, Malaysia
}

\begin{abstract}
Problem statement: The problem of students' proficiency in English in the Malaysian primary schools is still debatable. Approach: Unless the problem of students' proficiency is solved at the primary school level, it will fossilize and contribute toward students' anxiety in the language at the secondary and tertiary levels. Results: This research study looked into English needs of the indigenous or 'Orang Asli' students in primary schools in the district of Rompin-Endau, Pahang. These indigenous students still lag in education and with the implementation of teaching of science and mathematics in English in primary schools, they will be burdened with language difficulties. The researchers identify that the students preferred learning skill is listening to the teachers' explanation. And the task-based activity that can improve their proficiency is listening to songs and singing in English. Conclusion/Recommendations: Findings from this research could provide useful information for the curriculum developers at the Ministry of Education of Malaysia whether to revamp the present English curriculum or formulate a new curriculum to meet the English needs of the 'Orang Asli' students.
\end{abstract}

Key words: English needs, indigenous students, preferred skill, task-based activities

\section{INTRODUCTION}

Five years after the implementation of teaching of science and mathematics in English in Malaysian primary schools, the problem of students' proficiency in the language is still debatable. Unless the problem is solved at the primary level, it will fossilize and contribute toward students' anxiety in the language at the secondary and tertiary levels. Even the Ministry of Education of Malaysia has come out strongly with a statement that the decision on the teaching of science and mathematics in English has to wait. In uncertain terms the Ministry needs to make a rational assessment and is still skeptical of its implementation

The researchers will look into the English language needs of indigenous (in Malaysia it is known as 'Orang Asli') students in primary schools in the district of Rompin-Endau, Pahang. These students are studying in the peripheral schools which are fully funded by the government.

Research on English language needs of 'Orang Asli' students has not been done and the researchers feel that findings from this research could provide useful information to the curriculum developers at the Ministry of Education of Malaysia, whether to revamp the present curriculum or design a new curriculum specifically for the 'Orang Asli' students.

So the decision to use English for the teaching of science and mathematics in the primary schools, raises the issues of students' proficiency in the language. For the 'Orang Asli' students living in the peripherals, the implementation of this policy poses an added burden to them.

Looking in microcosm, the indigenous students still lag in education and with the implementation of teaching of science and mathematics in English in primary schools, these 'Orang Asli' students will be burdened with language difficulties. At the end of the day, these difficulties will erode their confidence and increase their anxiety toward acquisition of knowledge.

This research is based on the premise that it is essential to identify the students' preferred learning skills and task-based activities that can improve the students' proficiency in English. The following research questions will be investigated:

Corresponding Author: Shahrier Pawanchik, Department of English, School of Distance Education, University Sains Malaysia, 11800 USM, Penang, Malaysia Tel: 604653456 Fax: 6046576000 
- What are the students preferred learning skills in order of priorities?

- What are the task-based activities (in order of appropriateness) to improve students' proficiency?

Related literature review: The concept of 'needs' in today's English learning environment does not only refer to the needs of the learners but also takes into account the teaching institutions, the user-institutions (companies, business and banking) and even the larger spectrum-the society at large. It is important for the researchers to take into account the needs of the Ministry of Education as to why the learners need the language so that the curriculum is designed to include both the needs of the learners and the needs of the establishment.

'Need analysis has been defined as the identification of difficulties and standard situations by observation of participants functioning in a target situation in conjunction with interviews and questionnaires' (Basturkmen, 1998). And according to Basturkmen (1998) too what we are interested in is the gap between the target proficiency and the present proficiency.

According to Brindley (1989), needs can be divided into objective and subjective needs. The objective needs are derived from factual information about the learners and their usage of the language in real life situations. The learners' current language proficiency and difficulties are taken into consideration. However, the subjective needs refer to learners' wants and expectations. These are taken into consideration along with the language learning styles and strategies.

Widdowson (1987) provides two interpretations to the meaning of "learners' needs" and the first expression refers to what the learners need to do with the language once they have learned the language. This is goal-oriented of needs and needs related to terminal behaviors, the ends of learning. The second expression touches on what the learners need to do in order to actually acquire the language. This is a process-oriented definition of needs and needs related to transitional behaviors, the means of learning.

Before any course is drawn up, a learners' analysis has to be done. Nunan (1988) justifies needs analysis as 'Pedagogically, the most powerful argument in favor of a needs-based course is motivation. One way of improving motivation is to orientate content towards those areas that most interest learners and which are perceived by them as being more relevant'.

Wilkins (1976) however, states 'the first principle of a sound approach to language teaching is to know what the objectives of teaching are'. He mentions that it is necessary to predict what kind of language skills will be of greatest value to the learners. So it implies that a preliminary analysis of the learners' needs and expectations will be a prerequisite in any course design whether for general or specific purposes.

The above related reviews stress the importance of exploring needs before recommendations could be made for revamping a curriculum or designing a new curriculum for the students. Thus a course design must be focused towards meeting just the language needs of the learners.

Approach: The methodology underlying this research is guided by the protocol of Hutchinson and Waters (1987) and refined by Basturkmen (1998) model of needs analysis. It is both qualitative (exploratory interviews) and quantitative (implementation of structured questionnaires).

The researchers believe that information gathered from the questionnaires and triangulated with structured interviews with key informants, will permit considerable insights into the language needs of the 'Orang Asli' students.

The participants in this research are the 'Orang Asli' students from one of the sub-ethnic groups (the Jakuns) in two primary schools in the district of Rompin-Endau, Pahang-Sekolah Kebangsaan Labong and Sekolah Kebangsaan Tanah Abang. The researchers have taken the actual number of 'Orang Asli' enrolment for year six as samples-forty in Sekolah Kebangsaan Labong and ninety seven in Sekolah Kebangsaan Tanah Abang.

The researchers anticipate limitations in this research in elucidating information because these indigenous students do not feel at ease in answering the questionnaire. Thus the researchers have to translate the questionnaire into Malay (the national language) which the students are familiar with.

At the outset, the researchers have identified the students' class teachers who are teaching the subjects of science and mathematics in English as key informants. These teachers can be relied upon to give feedback on the language needs of the students. They have direct access to the students.

Results: Information gathered from the questionnaire is tabulated into Table 1 and 2.

As shown in Table $1(90 \%)$ and Table $2(90 \%)$, the students prefer learning by listening to the teachers' explanation. This skill is not too demanding. The researchers also found out, by elucidating from the class teachers that the students are able to grasp their teachers' explanations better because when explaining 
the science and mathematics terminologies, at times the teachers mixed English and Malay.

The second learning skill is writing and in this class activity the students copy notes from the board (Table 1; 93\% and Table 2; 89\%). It can be deduced that this task-based activity provides an opportunity for them to write in English and familiarize with the words or terminologies. It allows them to memorize and expand their vocabularies. The researchers triangulate these findings with information gathered from interviews with the teachers. The students are able to remember better after writing what the teachers have written on the white boards.

The third learning skill is reading text books. Table 1 shows $85 \%$ and Table 2 shows $81 \%$, the researchers found out from the teachers that the 'Orang Asli' students in year six are able to read in English and that is the reason for preferring this skill.

It can be seen that the students do not prefer the learning skill 'getting information for yourself'. Table $1(53 \%)$ and Table $2(39 \%)$ confirm the low percentage. The students are not keen to explore for the more information on their own. The teachers admit that the students have poor interest in facts finding and in most instances the teachers have to provide guidance.

Table $3(78 \%)$ and $4(79 \%)$ show that 'Orang Asli' students prefer singing and listening to songs. These activities are relaxing and an enjoyable language task. There is no pressure on the students to do well. The researchers elucidate this information from the teachers and found that the students look forward to these activities because they are less demanding. Culturally the students are attuned to singing.

And the second activity that they enjoy most is playing language games as can be seen from Table 3

(68\%) and Table 4 (67\%). The researchers cross check this information about the language games with their teachers and found that the students need to be guided. They enjoy this activity because they can share information with their friends.

The third activity identified by the researchers, as shown from Table $3(63 \%)$ and Table $4(66 \%)$, is 'getting information from planned visits,' the researchers found that these indigenous students are excited on any planned visits whether a visit to the zoo or the beach. This activity requires the students to speak and they are confident when doing presentation about their experience in a group. The teachers informed that such outdoor activities receive good response

Table 1: Sekolah Kebangsaan Labong, Rompin-Endau, Pahang

\begin{tabular}{llrl}
\hline Preferred learning & Yes & No & Percent yes \\
\hline Memorizing & 23 & 17 & 58 \\
Problem solving & 32 & 8 & 80 \\
Getting information for yourself & 21 & 19 & 53 \\
Listening to teacher's explanation & 36 & 4 & 90 \\
Reading & 34 & 6 & 85 \\
Writing & 37 & 3 & 93 \\
Listening and taking notes & 16 & 24 & 40 \\
Reading and making notes & 22 & 18 & 55 \\
Speaking: repeating what you hear & 22 & 18 & 55 \\
\hline
\end{tabular}

Table 2: Sekolah Kebangsaan Tanah Abang, Rompin-Endau, Pahang

\begin{tabular}{llll}
\hline Preferred learning & Yes & No & Percent yes \\
\hline Memorizing & 68 & 29 & 70 \\
Problem solving & 70 & 27 & 72 \\
Getting information for yourself & 38 & 59 & 39 \\
Listening to teacher's explanation & 87 & 10 & 90 \\
Reading & 79 & 18 & 81 \\
Writing & 86 & 11 & 89 \\
Listening and taking notes & 51 & 46 & 53 \\
Reading and making notes & 45 & 52 & 46 \\
Speaking: repeating what you hear & 57 & 40 & 59 \\
\hline
\end{tabular}

Table 3: Sekolah Kebangsaan Labong, Rompin-Endau, Pahang

\begin{tabular}{llrl}
\hline Task-based activities & Yes & No & Percent yes \\
\hline Role play & 15 & 25 & 38 \\
Language games & 27 & 13 & 68 \\
Songs & 31 & 9 & 78 \\
Talking with and listening to other students & 25 & 15 & 63 \\
Memorizing conversations/dialogues & 14 & 26 & 35 \\
Getting information from invited speakers & 12 & 28 & 30 \\
Getting information from planned visits (places of interest) & 25 & 15 & 63 \\
\hline
\end{tabular}

Table 4: Sekolah Kebangsaan Tanah Abang, Rompin-Endau, Pahang

\begin{tabular}{llll}
\hline Task-based activities & Yes & No & Percent yes \\
\hline Role play & 46 & 51 & 47 \\
Language games & 65 & 32 & 67 \\
Songs & 77 & 20 & 79 \\
Talking with and listening to other students & 48 & 49 & 50 \\
Memorizing conversations/dialogues & 40 & 57 & 41 \\
Getting information from invited speakers & 38 & 59 & 39 \\
Getting information from planned visits (places of interest) & 64 & 33 & 66 \\
\hline
\end{tabular}




\section{CONCLUSION}

From this research, the researchers indentify that the students prefer learning by listening to the teachers' explanation. The next learning skill is writing and in this class activity the students copy notes from the board The 'Orang Asli' students are at ease and confidence with these skills.

Listening to songs and singing in English is the most significant task-based activity identified by the researchers. This activity can enhance the students' acquisition of English. Furthermore these students are culturally attuned to songs. Naturally, they learn new words faster.

Playing language games is the second task-based activity chosen by the students because they are curious to learn about the games and in tandem enrich their vocabularies.

The Ministry of Education of Malaysia's policy on raising English proficiency of the students by teaching science and mathematics in English should be lauded. This method which is known as Content Based Instruction is very popular in the USA and Canada. It has proved particularly useful because it emphasizes on learning about something rather than learning about a language (Davies, 2003). Moreover, it is flexible and emphasizes both content and language goals. Using this 'language through content' method can instill interest in the students.

The grim reality of learning English is revealed when the researchers interviewed teachers who are teaching science and mathematics in English. Generally the answers that the researchers received are most of these indigenous students find English difficult and the teachers need to translate in Malay the science and mathematics terminologies. Thus it helps if the periods for teaching English are increased so that the students can receive more practice and drilling.

\section{REFERENCES}

Basturkmen, H., 1998. Refining procedures: A needs analysis project at Kuwait University. ERIC. http://eric.ed.gov/ERICWebPortal/search/detailmin i.jsp?_nfpb=true\&_\&ERICExtSearch_SearchValue _0=EJ599373\&ERICExtSearch_SearchType_0=no $\&$ accno=EJ599373

Brindley, G., 1989. Needs analysis and objectives setting in the adult migrant education program. NSW Adult Migrant Education Service.

Davies, S., 2003. Content based instruction in EFL contexts (TESL/TEFL). Internet TESL J., 9: 1-5. http://iteslj.org/Articles/Davies-CBI.html

Hutchinson, T. and A. Waters, 1987. English for Specific Purposes: A Learning-Centered Approach. 1st Edn., Cambridge University Press, Cambridge, ISBN: 10: 0521318378, pp: 192.

Nunan, D., 1988. Syllabus Design. 1st Edn., Oxford University Press, Oxford, ISBN: 10: 0194371395, pp: 176.

Widdowson, H.G., 1987. English for Specific Purposes. Criteria for Course Design. In: Methodology in TESOL: A Book of Readings, Long, M.H. and C. Richards (Eds.). Heinle ELT, New York, ISBN: 10: 0838426956, pp: 96-104.

Wilkins, D.A., 1976. Notional Syllabuses: A Taxonomy and its Relevance to Foreign language curriculum development. 7th Edn., Oxford University Press, London, ISBN: 0194370712, pp: 92. 